\title{
Chromium Accumulation by Avicennia alba Growing at Ecotourism Mangrove Forest in Surabaya, Indonesia
}

\author{
Harmin Sulistiyaning Titah ${ }^{1 *}$, dan Herman Pratikno ${ }^{2}$ \\ 1 Department of Environmental Engineering, Faculty of Civil, Environmental and Geo Engineering, Institut \\ Teknologi Sepuluh Nopember (ITS), Keputih, Sukolilo, 60111 Surabaya, Indonesia \\ 2 Department of Ocean Engineering, Faculty of Marine Technology, Institut Teknologi Sepuluh Nopember \\ (ITS), Keputih, Sukolilo, 60111 Surabaya, Indonesia \\ *Corresponding author's e-mail: harminsulis@gmail.com, harmin_st@its.ac.id
}

\begin{abstract}
The Ecotourism Mangrove Forest at Wonorejo in East Coast Surabaya area is one of large mangrove forests inside in the metropolitan city in Indonesia. There are many ecological values of the mangrove forest in most tropical countries such as sea fisheries, place of sea and coastal animals, sea and brackish water quality protecting the endangered mangrove coastlines and development of human life. The role of mangrove in increasing the sea and brackish water quality can be shown through many processes such as cycling of nutrients, particulate matter and some pollutants in water and sediment around the mangrove plants. One of the inorganic pollutants that can be removed by mangrove are heavy metals, such as chromium $(\mathrm{Cr})$. The Wonorejo River is one of the rivers that receive the disposal of wastewater in Surabaya East Coast area. Large quantitites of wastewater from industries and households were released to this river. The concentration of $\mathrm{Cr}$ at the Wonorejo Estuary reached $0.0325 \mathrm{mg} / \mathrm{L}$ and $2.7761 \mathrm{mg} / \mathrm{L}$ in sediments. The purpose of this research was to determine the potency of $\mathrm{Cr}$ accumulation by Avicennia alba that was grown for ten years at Wonorejo Ecotourism Mangrove Forest. The sampling activities were conducted using a transect quadrat sampling method with a $10 \times 10 \mathrm{~m}$ dimension. The sediment and mangrove root samples were extracted before being analysed using an atomic absorption spectrophotometer (AAS). The results showed that the $\mathrm{Cr}$ accumulation by roots of $A$. alba reached $25.4 \pm 1.6$ to $55.3 \pm 1.1$. The $\mathrm{BCF}$ value in $A$. alba were $0.32 \pm 0.01$ to $0.83 \pm 0.5$ with the concentration $\mathrm{Cr}$ in sediment were $60 \pm 1.4$ to $79.3 \pm 1.1$. A. alba showed potential as a moderate accumulator for $\mathrm{Cr}$. In conclusion, $A$. alba can be considered for use in phyto-monitoring and phytoremediation of $\mathrm{Cr}$ in coastal areas.
\end{abstract}

Keywords: Avicennia alba, BCF, coastal area, chromium, mangrove forest, root, sediment

\section{INTRODUCTION}

Some heavy metals such as iron (Fe), chromium $(\mathrm{Cr})$, copper $(\mathrm{Cu})$ and zinc $(\mathrm{Zn})$ are essential for the normal plant growth and development, being trace. However, they are also potentially toxic to the plant growth if the concentration of those heavy metals exceeds the normal concentration for plants (Asati et al., 2016). The increasing concentrations of $\mathrm{Cr}$ in some media such as air, fresh water, saline water or soil cause toxic effects on the metabolism of plants; thus, they inhibit the growth and development of plants leading to death in the worst case (Aydogan et al., 2017). Cr is needed for normal life processes; however it can be toxic to organisms at elevated concentrations at environment (Krishnani et al., 2004). Cr can affect the photosynthesis process of higher plants and trees through the processes of $\mathrm{CO}^{2}$ fixation, electron transport, photophosphorylation and enzyme activities in plants (Asati et al., 2016). The activity of heavy metals in seawater is more toxic in the ionic form compared with the other form of the metal, such as organic heavy metal compounds (Viarengo, 1989).

The estuary water contains some polutants such as inorganic polutants from the sewage system, industrial effluents, domestic and agricultural 
wastewater. Those sources of polutants consists of varying hazardous chemicals, thus they can cause negative effects on aquatic organisms (Krishnani et al., 2004). Many anthropogenic activities such as the electroplating industry and leather tanning industry can cause the increasing of concentrations of Cr in estuary area (Krishnani et al., 2004). The Wonorejo River is one of the rivers that discharge into the East Coast area in Surabaya. The wastewater from industry and households is dicharge to this river, so it can pollute the estuary area in Surabaya (BLH, 2012). The disposal of industrial waste, especially into the Wonorejo River was harmful to the environment because $\mathrm{Cr}$ could persist in that estuary. The concentration of $\mathrm{Cr}$ at the Wonorejo Estuary in 2007 reached $0.0325 \mathrm{mg} / \mathrm{L}$ and $2.7761 \mathrm{mg} / \mathrm{L}$ in sediments. The concentration of $\mathrm{Cr}$ at the Wonorejo estuary reached $0.418 \mathrm{mg} / \mathrm{L}$, based on KepMenLH No. 51 (2004), indicating it was above the water quality standard for marine biota $(0.005 \mathrm{mg} / \mathrm{L})$.

Actually, the Wonorejo Mangrove forest was started by the local community with the first purpose of preventing the sea water abrasion. The Wonorejo Mangrove forest areas in Surabaya is 64.83 ha in the total area of 133.98 ha. Nowdays, the ecotourism Mangrove Forest at Wonorejo in East Coast Surabaya area is one of large mangrove forests inside in the metropolitan city in Indonesia. Ecotourism is a natural resources activity in the form of tourism that is aimed at education, research, and conservation of the natural environment. Besides, the main of purpose is to increase the local economy near the location (Murtini et al., 2018). Ecotourism can accommodate tourists to explore the natural and local culture as well as the environment. They can learn more about the natural wealth owing to the ecotourism. Additionally, the ecotourism activities can increase the income for nature conservation and local communities. Besides the function as an ecotourism, there are many ecological values of a mangrove forest in most tropical countries such as sea fisheries, habitat of animals, increasing of estuary water quality protecting endangered mangrove coastlines and human life. Mangroves play a role in increasing estuary water quality that can be shown through the cycling of nutrients, pollutants, and particulate matter at surrounding the mangrove. One of inorganic pollutants that can be removed by mangrove includes heavy metals such as $\mathrm{Cr}$.

Avicennia marina is a mangrove species that has a high population in the Wonorejo Ecotourism
Mangrove Forest area with $88 \%$ of the total mangrove population. Meanwhile, the population of Avicennia alba corresponds to $11 \%$ of the total population. This area was planted with mangroves 10 years ago. The aim of this reserach was to determine the potency of $\mathrm{Cr}$ accumulation by Avicennia alba that was grown for ten years at Wonorejo Ecotourism Mangrove Forest.

\section{MATERIALS AND METHODS}

\section{Sampling Locations}

The sampling activities were conducted using a Transect quadrat sampling method. This is a sampling method of a population with a sample plot approach that is on a line drawn through the ecosystem. The dimension of one quadrant was $10 \mathrm{~m} \times 10 \mathrm{~m}$. The sampling point determinations were conducted using a GPSmap 76CSx (Garmin, USA). Figure 1 shows the sampling location, while the coordinates were shown in Table 1.

\section{Sampling of sediment and mangrove roots}

The sampling activities were conducted at around $7.00 \mathrm{am}$. The sea water level was low enough at that time for sediment sampling. According to Usman \& Mohamed's (2009) methods, the sediment sampling was carried out by random sampling at a depth of $0-30 \mathrm{~cm}$. According to Abohassan (2013), the concentrations of heavy metal did not show the difference at the $5-20 \mathrm{~cm}$ depths. The root samplings were conducted using a manual drill. All the samples were stored in an icebox at $4^{\circ} \mathrm{C}$; then, the samples were taken to the Environmental Remediation Laboratory, Department of Environmental Engineering, Institut Teknologi Sepuluh Nopember (ITS) for further analysis.

\section{Analysis of Chromium in Sediment and Roots of Mangrove}

First, all samples were prepared before being analysed by samples extracting. The $\mathrm{Cr}$ analysis in sediment and mangrove root was conducted using an atomic absorption spectrophotometer (AAS). The AAS was used to measure the concentration of $\mathrm{Cr}$ in the sediment and A. alba roots. The model of AAS instrument used was a Rayleigh WFX 210 (China). The AAS analysis was conducted in 


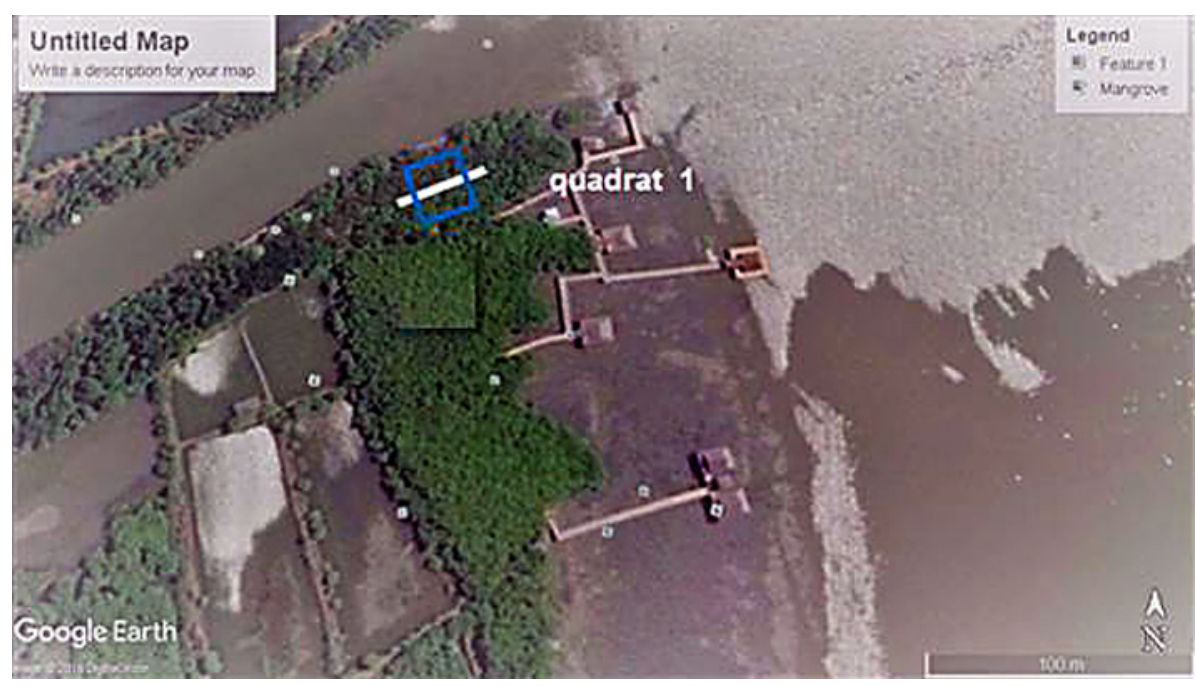

Figure 1. Sampling Locations

Table 1. Coordinate of Sampling Locations

\begin{tabular}{|c|c|c|}
\hline No & Sampling code & Coordinate of samplings \\
\hline 1 & A21A & $\begin{array}{l}S=07^{0} 18^{\prime} 21,0^{\prime \prime} \\
E=112^{\circ} 50^{\prime} 39,5^{\prime \prime}\end{array}$ \\
\hline 2 & A22A & $\begin{array}{l}S=07^{0} 18^{\prime} 21,1^{\prime \prime} \\
E=112^{\circ} 50^{\prime} 39,4^{\prime \prime}\end{array}$ \\
\hline 3 & A21B & $\begin{array}{l}S=07^{0} 18^{\prime} 20,7^{\prime \prime} \\
E=112^{\circ} 50^{\prime} 39,1^{\prime \prime}\end{array}$ \\
\hline 4 & A22B & $\begin{array}{l}S=07^{0} 18^{\prime} 20,7^{\prime \prime} \\
E=112^{\circ} 50^{\prime} 39,0^{\prime \prime}\end{array}$ \\
\hline 5 & A21C & $\begin{array}{l}S=07^{0} 18^{\prime} 20,4^{\prime \prime} \\
E=112^{\circ} 50^{\prime} 39,2^{\prime \prime}\end{array}$ \\
\hline 6 & A22C & $\begin{array}{l}S=07^{0} 18^{\prime} 20,5^{\prime \prime} \\
E=112^{\circ} 50^{\prime} 39,1^{\prime \prime}\end{array}$ \\
\hline 7 & A21D & $\begin{array}{l}S=07^{0} 18^{\prime} 20,6^{\prime \prime} \\
E=112^{\circ} 50^{\prime} 39,4^{\prime \prime}\end{array}$ \\
\hline 8 & A22D & $\begin{array}{c}S=07^{0} 18^{\prime} 20,6^{\prime \prime} \\
E=112^{\circ} 50^{\prime} 39,42^{\prime \prime}\end{array}$ \\
\hline 9 & A21E & $\begin{array}{l}S=07^{0} 18^{\prime} 20,9^{\prime \prime} \\
E=112^{\circ} 50^{\prime} 39,7^{\prime \prime}\end{array}$ \\
\hline 10 & A22E & $\begin{array}{c}S=07^{0} 18^{\prime} 20,9^{\prime \prime} \\
E=112^{\circ} 50^{\prime} 39,8^{\prime \prime}\end{array}$ \\
\hline
\end{tabular}

the Department of Chemical Engineering, ITS, at the Laboratory of Affiliation Team and Industry Consultation (TAKI).

The roots of $A$. alba were dried before extraction. The Cr extraction from roots of A. alba was conducted using a modified wet digestion method. The modified wet digestion method was carried out based on Titah et al. (2013). Meanwhile, the sediment extraction was performed with the EPA method 3050B (1996).

\section{Bio-concentration Factor}

The Bioconcentration Factor (BCF) or Biological Accumulation Coefficient (BAC) calculation (Bini et al. 1995) was used to gauge the ability of the plants to take up metal from the substrate (Idris et al., 2016). The determination for $\mathrm{BAC}$ was based on the following equation.

$$
B C F=\frac{C_{\text {roots }}}{C_{\text {media }}}
$$

\section{RESULTS AND DISCUSSION}

The average concentration of $\mathrm{Cr}$ in $A$. alba roots ranged from $25.4 \pm 1.6$ to $55.3 \pm 1.1 \mathrm{mg} / \mathrm{kg}$ (Figure 2). This result showed that $A$. alba could take up $\mathrm{Cr}$ and accumulate it in their roots. On the basis of the previous study, the value of $\mathrm{Cr}$ in roots of Avicennia marina in mangove forest ranged from $28 \mathrm{mg} / \mathrm{kg}$ to $92.25 \mathrm{mg} / \mathrm{kg}$ (Pratikno et al., 2017). According to Peters et al. (1997), mangrove plants trend to uptake and than to accumulate heavy metals such as $\mathrm{Cu}, \mathrm{Zn}, \mathrm{Pb}, \mathrm{Fe}, \mathrm{Mn}$ and $\mathrm{Cd}$ is observed primarily in the root tissue, rather than in their foliage. This phenomenon occured in such mangrove species as Avicennia spp., Rhizophora spp. and Kandelia spp. The continuous accumulation of heavy metals and the filtration of heavy metals in roots of mangrove plants at a long period of time can cause higher heavy metal concentration in roots compared to the sediment (Abohassan, 2013). Heavy metals can be immobilized in root so the concentration of heavy metals is higher in roots than in other parts of plants. According to Basta et al. (2005), the mechanism of heavy metals involved immobilization in root, i.e. a bioavailable heavy metal fraction was sorbed at root surface, then the bioavailable metal moved across to the cellular membrane into root cells; 
thus a heavy metal absorbed into roots was immobilized in the vacuole of the root.

The average concentration of $\mathrm{Cr}$ in the sediment near $A$. alba ranged from $60 \pm 1.4$ to $79.3 \pm 1.1 \mathrm{mg} / \mathrm{kg}$ (Figure 2). According to the Canadian sediment quality guidelines, some concentrations of $\mathrm{Cr}$ at some sampling points were above the standard. The standard for $\mathrm{Cr}$ concentration based on those regulations was $52.3 \mathrm{mg} / \mathrm{kg}$. It indicated contamination at those areas. This condition occurred due to the dicharge of wastewater from industry and households to this river, causing pollution at the estuary area. On the basis of our previous study, the average value of $\mathrm{Cr}$ concentration in the sediment in the surrounding of $A$. marina grown ranged from $47 \mathrm{mg} / \mathrm{kg}$ to $66.5 \mathrm{mg} / \mathrm{kg}$ (Pratikno et al., 2017). It was predicted that many other heavy metals are concentrated in the sediments of this area. According to Rachmawati et al. (2018), the concentrations of $\mathrm{Cu}$ were $4.13-36.95 \mathrm{ppm}$ and $\mathrm{Pb}$ were 3.28 - $23.79 \mathrm{ppm}$. Sari et al. (2017) reported that certain concentrations of $\mathrm{Hg}$ and $\mathrm{Cu}$ were detected at Wonorejo coastal area.

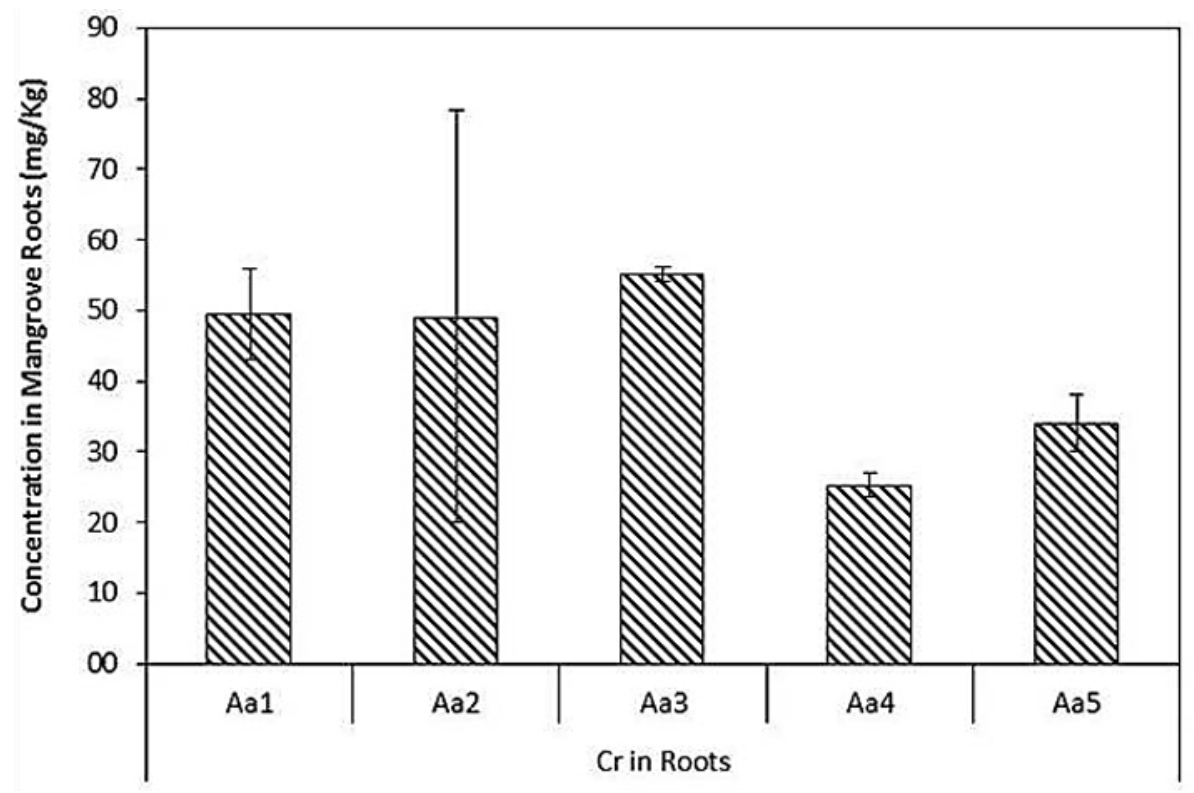

Figure 2. Concentration of $\mathrm{Cr}$ in Mangrove Root of $A$. alba $(\mathrm{Aa}=$ Avicennia alba $)$

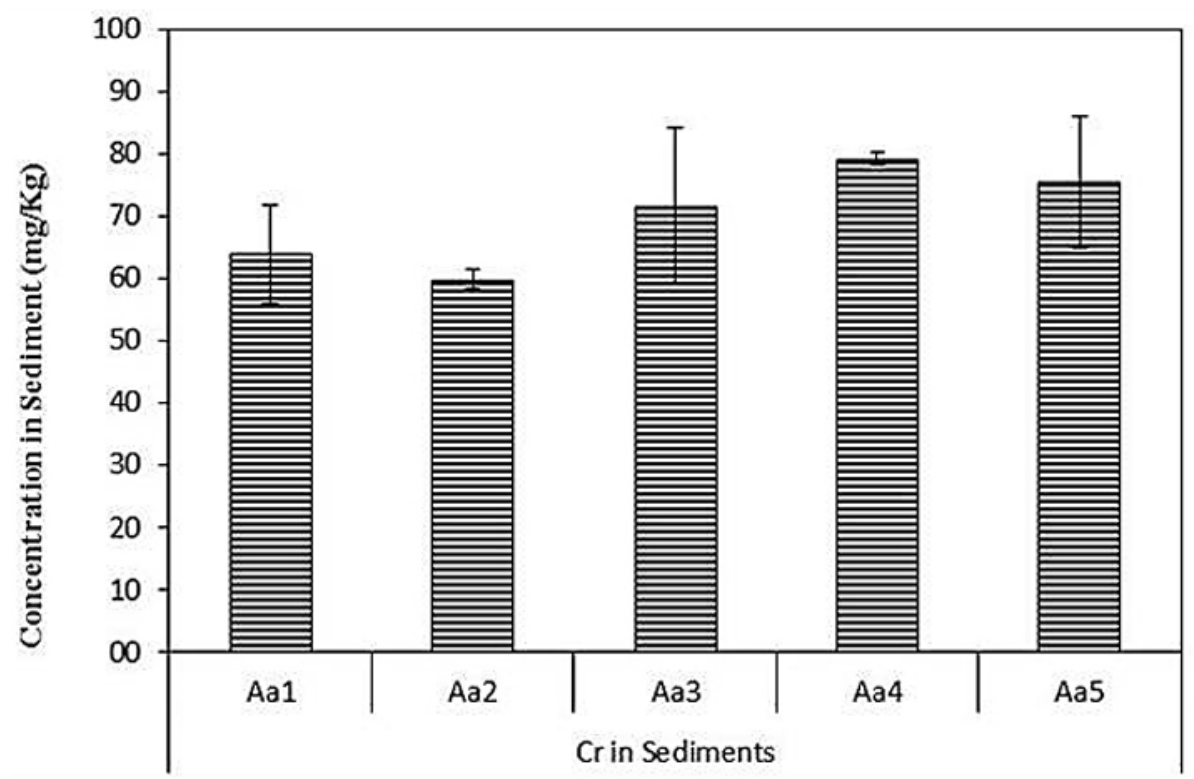

Figure 3. Concentration of $\mathrm{Cr}$ in Sediments $(\mathrm{Aa}=$ Avicennia alba $)$ 
The BCF value was calculated using equation 1. The BCF value in $A$. alba were $0.32 \pm 0.01$ to $0.83 \pm 0.5$. On the basis of the plant classification (Bini et al., 1995), A. alba showed potential as a moderate accumulator for $\mathrm{Cr}$. This result indicates that $A$. alba was taken up $\mathrm{Cr}$ from sediment and $A$. alba was included as an accumulator plant for Cr. Rodríguez-Iruretagoiena et al. (2016) reported that A. alba showed a good accumulation potential because this plant can accumulate $\mathrm{Al}, \mathrm{Cd}, \mathrm{Co}, \mathrm{Cr}, \mathrm{Cu}, \mathrm{Ni}, \mathrm{Mn}$ and $\mathrm{Zn}$. It was considered that $A$. alba constitutes an efficient accumulator plants. Some species accumulated metals in shoots; however, they cannot be classified as hyperaccumulators since the metal concentrations were not sufficiently high to fit the criteria for plants in a phytoextraction strategy, even those with TF $>1$ and BCF $>1$ such as Thespesia populnea for $\mathrm{Ni}$ and Cyperus involucratus for $\mathrm{Cr}$.

On the basis of the data, the A. alba grown at Ecotourism Mangrove Forest, Wonorejo in East Coast Surabaya can take upCr from sediments and accumulate it in their roots. A. alba can control the concentration of $\mathrm{Cr}$ in the enviroment, especially in the sediments near those plants which grew by taking up and accumulating $\mathrm{Cr}$. The Ecotourism Mangrove Forest, Wonorejo in East Coast Surabaya can be used for phyto-monitoring and phytoremediation of $\mathrm{Cr}$, so that the negative effect of $\mathrm{Cr}$ on ogranisms and environment can be reducted.

\section{CONCLUSION}

The $\mathrm{Cr}$ accumulation by roots of $A$. alba reached $25.4 \pm 1.6$ to $55.3 \pm 1.1$. The BCF value in $A$. alba were $0.32 \pm 0.01$ to $0.83 \pm 0.5$ with the concentration $\mathrm{Cr}$ in sediment in the range from $60 \pm 1.4$ to $79.3 \pm 1.1$. A. alba showed potential as a moderate accumulator for $\mathrm{Cr}$. In conclusion, A. alba can be considered for use in phyto-monitoring and phytoremediation of $\mathrm{Cr}$ in coastal areas.

\section{Acknowlegement}

The authors would like to thank Lembaga Penelitian dan Pengabdian kepada Masyarakat, Institut Teknologi Sepuluh Nopember - ITS Research Centre, through Laboratory Research Grant for funding this research and Direktorat Pengelolaan Kekayaan Intelektual Direktorat Jenderal Penguatan Riset dan Pengembangan, Ministry of Research, Technology and Higher Education through BSLN (Bantuan Seminar Luar Negeri) in 2019.

\section{REFERENCES}

1. Abohassan, R.A. 2013. Heavy Metal Pollution in Avicennia marina Mangrove Systems on the Red Sea Coast of Saudi Arabia. Metrology, Environment

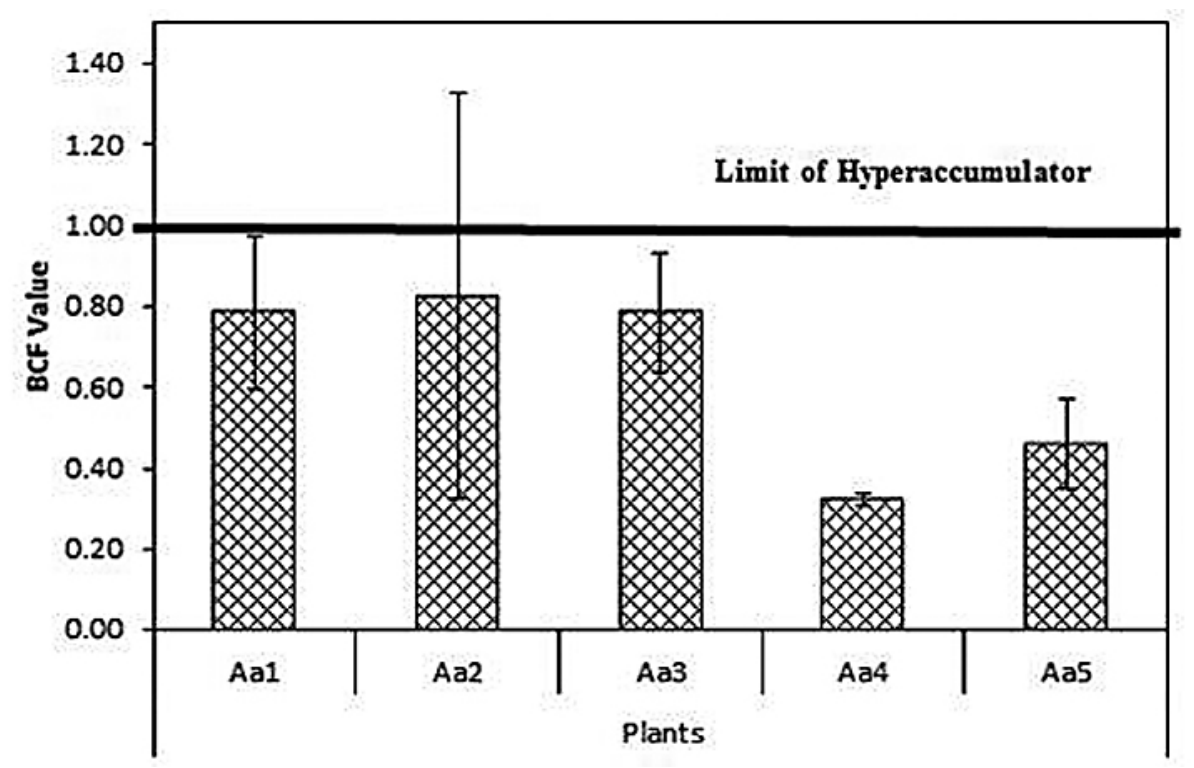

Figure 4. BCF Value, $(\mathrm{Aa}=$ Avicennia alba $)$ 
and Arid Land Agricultural Sciences, 24(1), 35-53.

2. Asati, A., Pichhode, M., and Nikhil, K. 2016. Effect of Heavy Metals on Plants: An Overview. International Journal of Application or Innovation in Engineering \& Management, 5(3), 56-66.

3. Aydoğan, S., Erdağ, B., and Aktaş L. Y. 2017. Bioaccumulation and oxidative stress impact of $\mathrm{Pb}, \mathrm{Ni}$, $\mathrm{Cu}$, and $\mathrm{Cr}$ heavy metals in two bryophyte species, Pleurochaete squarrosa and Timmiella barbuloides. Turkish Journal of Botany, 41, 464-475.

4. Badan Lingkungan Hidup Kota Surabaya. 2012. Laporan Pengendalian Kawasan Pesisir dan Laut Tahun 2012, Report on Pollution Prevention at Coastal and Sea in 2012.

5. Bini, C. L., Gentili, L., Maleci, B., and Vaselli, O. 1995. Trace elements in plant and soils of urban parks. Annexed to contaminated soil prost. INRA, Paris.

6. EPA. 1996. Method 3050b acid digestion of sediments, sludges, and soils.

7. Idris, M., Abdullah, S.R.S., Titah, H.S., Latif, M.T., Abasa, A.R., Husin, A.K., Hanima, R.F., and Ayub, R. 2016. Screening and Identification of Plants at a Petroleum Contaminated Site in Malaysia For Phytoremediation. Journal of Environmental Science and Management, 19(1), 27-36

8. Keputusan Menteri Negara Lingkungan Hidup Nomor 51. (2004). Baku Mutu Air Laut, Sea Standard.

9. Krishnani, Parimala, V., and Meng, X. 2004. Detoxification of chromium (VI) in coastal water using lignocellulosic agricultural waste Kishore K. Water SA, 30 (4), 541-546.

10. Meeinkuirt, W, Kaewtubtim, P., Seepom, S., and Pichtel, J. 2017. Metal Uptake and Accumulation by Mangrove Plant Species in Pattani Bay, Thailand. Proceedings of the 3 rd World Congress on New Technologies (NewTech'17) Rome, Italy, June 6-8.

11. Murtini, S., Kuspriyanto, and Kurniawat, A. 2018. Mangrove area development strategy Wonorejo as ecotourism in surabaya. Journal of Physics: Conference Series. 593: 1-5.

12. Peters E.C., Gassman N.J., Firman J.C., Richmond
R.H., \& Power E.A. 1997. Ecotoxicology of tropical marine ecosystems. Environmental Toxicology and Chemistry, 16, 12-40.

13. Pratikno, H., Titah, H.S., Handayanu, and Harnani, B.R.D. 2017. The ability of Avicennia marina (Apiapi putih) to Uptake Heavy Metal of Chromium at Wonorejo Coastal in Surabaya. Proceedings of International Conference : Problem, Solution and Development and Delta Area.

14. Basta, N.T., Ryan, J.A., and Chaney, R.L. 2005. Trace element chemistry in residual-treated soil: key concepts and metal bioavailability. Journal of Environmental Quality, 34(1), 49-63.

15. Rachmawati, Yona, D., and Kasitowati, R.D. 2018. Potential of Avicennia Alba as An Agent of Phytoremediation Heavy Metal $(\mathrm{Pb}$ and $\mathrm{Cu})$ in Wonorejo, Surabaya. Jurnal Kelautan, 11(1), 80-87.

16. Rodríguez-Iruretagoiena, A., Chowdhury, R., Gredilla, A., deVallejuelo, S.F., de Diego, A.., Sarkar, S.K., Arana, G., Madariaga, J.M., and Venkatachalam, P. 2016. Uptake and Distribution of Trace Elements in Dominant Mangrove Plants of the Indian Sundarban Wetland. Bulletin of Environmental Contamination and Toxicology, 97(5), 721-727.

17. Sari, S. H. J., Kirana, J. F. A., and Guntur, G. 2017. Analisis Kandungan Logam Berat $\mathrm{Hg}$ dan $\mathrm{Cu}$ Terlarut di Perairan Pesisir Wonorejo, Pantai Timur Surabaya. Jurnal Pendidikan Geografi: Kajian, Teori, dan Praktek dalam Bidang Pendidikan dan Ilmu Geografi. 22(1).

18. Titah, H.S., Abdullah, S.R.S., Mushrifah, I., Anuar, N., Basri, H., and Mukhlisin, M. 2013. Effect of applying rhizobacteria and fertilizer on the growth of Ludwigia octovalvis for arsenic uptake and accumulation in phytoremediation. Ecological Engineering, 58, 303-313.

19. Usman A.R.A and Mohamed, H.M. 2009. Effect of microbial inoculation and EDTA on uptake and translocation of heavy metals by corn and sunflower. Chemosphare, 76, 893-899.

20. Viarengo, A. 1989. Heavy metals in marine vertebrates: Mechanism of regulation and toxicity at the cellular level. Review Aquatic. Science 1(295). 